\title{
Contextual Effect of Community Health Center and Other Determinants of Midwife Performance in the Implementation in the Prevention Mother to Child Transmission Counselling and Testing: A Multilevel Model Evidence
}

\author{
Sringatin 1,2), Uki Retno Budihastuti3), Endang Sutisna Sulaeman4) \\ 1)Dolopo Regional Public Hospital, Madiun, East Java \\ 2) Masters program in Public Health, Univesitas Sebelas Maret, Surakarta \\ 3) Department of Obstetric and Gynecology, Dr. Moewardi Hospital \\ 4) Faculty of Medicine, Univesitas Sebelas Maret, Surakarta
}

\section{ABSTRACT}

Background: High transmission of HIV from mother to child can contribute to an increase in the number of pandemic events. Transmission of HIV from mother to baby can be prevented by the PMTCT (Prevention of Mother to Child HIV Transmission) program. The purpose of this study is to analyze the implementation of PMTCT program policies by midwives.

Subjects and Method: The design used in this study was observational analytic with cross sectional approach. The number of samples is 184 subjects. The sampling was done using total sampling. The independent variables included midwives' knowledge, midwife's age, job satisfaction, team performance, work environment, community support, training, and length of work. Meanwhile, the dependent variable is the implementation of PMTCT policies. Variable data collection was performed using a questionnaire and analyzed using multilevel analysis with Stata 13. Results: The implementation of PMTCT policies increased influenced by period of working $\geq 8$ years $(b=0.50 ; 95 \% \mathrm{CI}=0.61$ to $0.85 ; \mathrm{p}=0.004)$, training $\geq 2$ times $(\mathrm{b}=0.44 ; 95 \% \mathrm{CI}=-0.13$ to $0.76 ; \mathrm{p}=0.005)$, good midwife knowledge $(\mathrm{b}=$ $0.65 ; 95 \% \mathrm{CI}=0.36$ to 0.93 ; $\mathrm{p}<0.001$ ), midwife satisfaction is good $(b=0.05 ; 95 \% \mathrm{CI}=-0.21$ to
$0.31 ; \mathrm{p}=0.694)$, and midwife performance is $\operatorname{good}(b=0.59 ; 95 \% \mathrm{CI}=0.25$ to $0.93 ; \mathrm{p}=0.001)$. The implementation of PMTCT policies decreased influenced by bad working environment $(\mathrm{b}=$ $0.09 ; 95 \% \mathrm{CI}=-0.36$ to $0.16 ; \mathrm{p}=0.451)$, age $\geq 35$ years $(b=-0.51 ; 95 \% \mathrm{CI}=-0.80$ to $-0.24 ; \mathrm{p}<$ 0.001), and small community support $(\mathrm{b}=-0.06$; $95 \% \mathrm{CI}=-0.38$ to $0.25 ; \mathrm{p}=0.692)$. Public health centers have weak contextual influence on the implementation of PMTCT program policies with ICC $=6.6 \%$.

Conclusion: The midwife's period of work, knowledge, training, midwife's performance, and midwife's satisfaction improve PMTCT implementation. Whereas midwives' age, work environment and community support reduce PMTCT implementation.your text here

Keywords: HIV/AIDS, implementation of PMTCT, multiple linear regression analysis.

\section{Corspondence:}

Sringatin, Dolopo Regional Public Hospital, Madiun, East Java. Jl. Raya Dolopo no.117 Dolopo, Madiun 63174, East Java. Email: sringatine22@gmail.com. Mobile: 081231683090

\section{Cite this as:}

Sringatin, Budihastuti UR, Sulaeman ES (2020). Contextual Effect of Community Health Center and Other Determinants of Midwife Performance in the Implementation in the Prevention Mother to Child Transmission Counselling and Testing: A Multilevel Model Evidence. J Health Policy Manage. 5(1): 35-47.

https://doi.org/10.26911/thejhpm.2020.05.01.04

Journal of Health Policy and Management is licensed under a Creative Commons Attribution-Non Commercial-Share Alike 4.o International License.

\section{BACKGROUND}

A number of developing countries found HIV/AIDS as the main cause of death of women of reproductive age. HIV/AIDS is a health issue that is sensitive enough to be investigated. This is related to the unique 
nature of this disease. In addition to cases such as the phenomenon of the iceberg, stigma and discrimination are also experienced by many sufferers and their families.

Ministry of Health's 2018 report in the period January 1, 2017 to December 2017 reported the number of people infected with HIV/AIDS reaching 19,385 people. The highest incidence of HIV occurs in the age group of 25-49 years with a percentage of $69.2 \%$ with a ratio between men and women 2: 1 .

The Madiun District Health Office notes that from 2004 to the end of February 2019, 682 positive people had been found to be infected with HIV or people with HIV/ AIDS (PLWHA). Of these, the average age is dominated by around 31-40 years (35\%) and ages 21-30 years (33\%). However, it is estimated that the number of HIV/AIDS sufferers in Madiun District has reached 930 people (Madiun, 2013)

Prevention of HIV transmission from mother to baby is one of the great successes of public health over the past 20 years (Hurst et al, 2015). Transmission of HIV from mother to baby can be prevented by the PMTCT (Prevention of Mother to Child HIV Transmission) program. The risk of a baby getting HIV from his mother in a developed country is around $<2 \%$, this is due to the availability of optimal services to prevent HIV transmission from mother to baby. But in developing countries or poor countries with minimal intervention access, the risk of transmission increases to between $25 \%-45 \%$. People often assume that babies born to HIV positive mothers will definitely be infected with the HIV virus. In fact, $60 \%-75 \%$ of these children are not infected even though there is no intervention. The spread of HIV can occur $5 \%$ during pregnancy, $15 \%$ at delivery, and 10\% through breastfeeding (Read et al. 2007).

Efforts to prevent HIV transmission from mother to baby are known as prevention of HIV transmission from mother to child is an effective strategy and covers a wide spectrum, not only to housewives, but also to female sex workers, injecting drug users, migrant workers and so on by paying attention to human rights and gender-sensitive services. The mother-to-child HIV transmission prevention program has two objectives, namely: (1) to prevent mother-to-child HIV transmission, because $90 \%$ of HIV infections in infants are caused by mother-to-child transmission and only about $10 \%$ occurs because of the transfusion process, (2) reduce the impact of the HIV epidemic on mothers and babies (Ministry of health, 2008).

To anticipate the spread of the HIV/ AIDS virus in the Madiun Regency, the Madiun District Government through the Health Office is implementing a program to prevent HIV transmission from child mothers (PMT$\mathrm{CT})$. At present, every pregnant woman in Madiun Regency is required to conduct VCT examinations in 26 Public Health Centers and 2 hospitals owned by the regional government in Madiun Regency, including Mejayan, Madiun, Balerejo, and Bangunsari community health centers. The Health Office is intensively conducting socialization and counseling to students at each school level by optimizing cadres and preparing HIV diagnosis facilities in the form of Voluntary Counseling and Testing (VCT) services in each community health centers, Dolopo Regional Hospital, and Panti Waluyo Regional Hospital (Duta, 2018).

Prevention of HIV transmission from mother to child is a program of prevention of HIV transmission from mother to child carried out in an integrated and comprehensive manner with other programs relating to controlling HIV and AIDS through the 4 program strategy. The purpose of the PMTCT program is to reduce HIV transmission from mothers to their babies, with the target of the program being pregnant women, babies born, women of reproductive age, adoles- 
cents and young people. Program activities 1 and 2 can be implemented at all levels and the Health Service Unit (UPK) while programs 3 and 4 are implemented at UPK and higher facilities can generally be obtained at Hospitals (Hospitals). The following also needs to be carried out in the implementation of PMTCT: integrated MCH services, voluntary counseling and testing services, prophylactic ARV drug administration, counseling about HIV and nutriational choices for infants, safe delivery. Midwives are one part of health services that spearhead in providing $\mathrm{MCH}$ and $\mathrm{KB}$ services, and can also be a network within the reach of pregnant women.

Midwives can act as health educators and counseling pregnant women about risky behavior for HIV and AIDS transmission, providing information about VCT/PMTCT, not only in women, but also in families and communities. In addition midwives can also play a role in surveillance of cases of sexually transmitted diseases (STDs), which increase the risk of contracting HIV and AIDS. The success of midwives in carrying out their duties requires support from various related parties such as: stakeholders, non-governmental organizations (NGOs), and is also supported by facilities, information facilities, skills and policies through the midwife capacity building program as a health educator and counseling to pregnant women in prevention efforts transmission of HIV and AIDS (Ministry of Health, 2018).

The role of midwives as professionals and is one of the health personnels who have an important and strategic position, especially in reducing Maternal Mortality Rate (MMR) and Infant Mortality Rate (IMR). Midwives as the spearhead of health services for pregnant women, birth and maintenance of maternal and child health, have a strategic role in efforts to suppress the growth rate of HIV/AIDS among community groups visiting Public Health Centers and Hospitals, especially in $\mathrm{MCH} / \mathrm{KB}$ services. Midwives are trained to have knowledge about preventing transmission of HIV/AIDS from mother to baby (Widjajanti, 2016).

This study aims to analyze the Policy Implementation of HIV transmission programs from child mothers (PMTCT) by Midwives.

\section{SUBJECTS AND METHOD}

\section{Study Design}

The design used in this study was an observational analytic study with a cross sectional approach. It employed multilevel multiple linear regression analysis techniques in which there were two levels that became subjects, namely at level I (individual) and level II (community). The individual level in this study was the midwife who works at the Public Health Centers while at the community level is the Public Health Centers. This study was conducted in August-September 2019.

\section{Population and Sample}

The target population in this study is Midwives in Madiun Regency with the source population being Midwives who work in Public Health Centers in Madiun District. Samples are selected by Total Sampling. At the community level, 26 Public Health Centers were selected with different Public Health Centers accreditations, namely Elementary, Intermediate, Primary, and Plenary. At the individual level, a total of 184 subjects were selected.

\section{Study Variables}

The dependent variable was the implementation of PMTCT program policies by midwives. The independent variables are midwife knowledge, period of working, midwife's age, job satisfaction, team performance, work environment, community support, and training. 4. Operational Definition of Variables Midwife's age is a life span measured by years or can also be the length of life in the year calculated from birth. The data collect- 
ion was done using questionnaire. The scale of the data was continuous, and for the purposes of data analysis, it was changed to a dichotomy.

The period of working is the period of time to carry out an activity or the length of time someone has worked in a place. The data collection was done using questionnaire. The scale of the data was continuous, and for the purposes of data analysis, the data was converted into a dichotomy.

Midwife's knowledge is an intellectual ability and level of understanding, especially midwives' knowledge of the application of PMTCT services according to standards. The data collection was done by using questionnaires. The measurement of the scale of the data was continuous, and for the sake of data analysis, the data was converted into a dichotomy.

Decree of assignment is an official letter made and issued by an authorized official in a particular agency or institution where the contents assign an employee/staff to do a job. The data collection was carried out by questionnaire. The measurement scale was dichotomous data.

Job satisfaction was a general attitude towards one's work that shows the difference between the amount of appreciation received by workers and the amount they are supposed to receive. Data collection was carried out using a questionnaire. The scale of the data collection was continuous, and for the purposes of data analysis, the data was converted into a dichotomy.

Team performance is a team that does the right things, in order to achieve the targets given by the boss. The data collection was carried out using a questionnaire. The scale of data retrieval was continuous, and for the purposes of data analysis, the data was converted into a dichotomy.

Working environment is something that is around the workers and that affects them in carrying out the tasks that are assigned. Data collection was carried out using a questionnaire. The measurement of the scale of the data was continuous, and for the purposes of data analysis the data was converted into a dichotomy.

Community support is a form of attention, appreciation, enthusiasm, acceptance, and assistance in other forms that have social relations. The data collection was carried out using a questionnaire. The measurement of the scale of the data was continuous, and for the sake of data analysis, the data was converted into a dichotomy.

Training is a planned effort to facilitate learning about work related to knowledge, skills and behavior by employees. The data collection was carried out using a questionnaire. The measurement of the scale of the data was continuous, and for the purposes of data analysis the data was converted into a dichotomy.

Public Health Center accreditation is an acknowledgment of Public Health Centers given by an independent accreditation provider by assessing that the Public Health Centers has met service standards. The data collection was carried out using a questionnaire. The measurement of the scale of the data was continuous, and for the sake of data analysis, the data was converted into a dichotomy.

\section{Data Analysis}

Univariate analysis was performed to describe the characteristics of the variables based on the results of the study. Bivariate analysis was performed to determine the relationship between the independent variables with the dependent variable using the chi-square test. Multivariate analysis was performed using multilevel multiple linear regression analysis.

\section{Research Ethic}

The research ethics in this study included the consent sheet, anonymity, confidentiality, and ethical eligibility. Ethical feasibility in 
Sringatin et al./Contextual Effect of Community Health Center and Other

this study came from the Health Research

Ethics Committee of Dr. Moewardi Hospital Surakarta with number: 1.083/IX/HREC/2019.

\section{RESULTS}

\section{Univariate analysis}

Tables 1 and 2 showed the characteristics of respondents and other variables, using continuous data and categorical data.

Table 1. Sample Characteristics (continuous data)

\begin{tabular}{lccccc}
\hline \multicolumn{1}{c}{ Variable } & n & Mean & SD & Min. & Max. \\
\hline Accreditation Status & 184 & 1.84 & 0.59 & 1 & 3 \\
Age & 184 & 35.62 & 6.65 & 24 & 52 \\
Period of working & 184 & 8.65 & 5.14 & 1 & 25 \\
Knowledge & 184 & 8.52 & 0.92 & 4 & 10 \\
Satisfaction & 184 & 22.23 & 2.26 & 18 & 31 \\
Environment & 184 & 19.09 & 2.37 & 14 & 32 \\
Performance of team & 184 & 9.97 & 0.23 & 8 & 10 \\
Public support & 184 & 8.67 & 1.12 & 7 & 10 \\
\hline
\end{tabular}

Table 2. Sample characteristics (categorical data)

\begin{tabular}{|c|c|c|}
\hline Variables & Frequency (n) & Percentage (\%) \\
\hline \multicolumn{3}{|c|}{ PMTCT Implementation } \\
\hline Poor & 97 & 52.7 \\
\hline Good & 87 & $47 \cdot 3$ \\
\hline \multicolumn{3}{|c|}{ Midwife knowledge } \\
\hline Poor & 99 & 53.8 \\
\hline Good & 85 & 46.2 \\
\hline \multicolumn{3}{|c|}{ Job Satisfaction } \\
\hline dissatisfied & 136 & $73 \cdot 9$ \\
\hline satisfied & 48 & 26.1 \\
\hline \multicolumn{3}{|c|}{ Performance of team } \\
\hline Poor & 4 & 2.2 \\
\hline Good & 180 & 97.8 \\
\hline \multicolumn{3}{|c|}{ Working environment } \\
\hline Poor & 127 & 69 \\
\hline Good & 57 & 31 \\
\hline \multicolumn{3}{|c|}{ Public Support } \\
\hline Poor & 72 & 39.1 \\
\hline Good & 112 & 60.9 \\
\hline \multicolumn{3}{|l|}{ Training } \\
\hline No training & 105 & 57.6 \\
\hline Training & 78 & 42.4 \\
\hline \multicolumn{3}{|l|}{ Tenure } \\
\hline Short & 107 & 58.2 \\
\hline Long & 77 & 41.8 \\
\hline \multicolumn{3}{|c|}{ Decree of assignment } \\
\hline No & 23 & 12.5 \\
\hline Yes & 161 & 87.5 \\
\hline \multicolumn{3}{|c|}{ Public Health Centers accreditation } \\
\hline Basic & 30 & 16.30 \\
\hline Madya & 141 & 76.63 \\
\hline Primary & 13 & 7.07 \\
\hline
\end{tabular}

\section{The result of bivariate analysis}

Table 3 shows the results of the bivariate analysis between the dependent variable and the independent variable.

There was a relationship between the age of midwives and the implementation of 
the PMTCT program, midwives aged $\geq 35$ years (64.84\%) were more likely to implement PMTCT better than age $<35$ years (48.39\%) and the difference was statistically significant $(\mathrm{OR}=1.97 ; \mathrm{p}=0.024)$.

There is a correlation between the length of work and the implementation of the PMTCT program, midwives who have a work period of $\geq 8$ years $(84.95 \%)$ are more likely to implement PMTCT better than the working period of $<8$ years $(27.47 \%)$ and the difference is statistically significant $(\mathrm{OR}=$ 14.9; $\mathrm{p}<0.001$ ).

There is a relationship between PMTCT training and PMTCT program implementation, midwives who participated in training $\geq 2$ times (80.90\%) implemented PMTCT more well than those who participated in training <2 times (33.68\%) and the difference was statistically significant $(\mathrm{OR}=$ 8.34; $\mathrm{p}<0.001$ ).

There is a relationship between midwives' knowledge and PMTCT program implementation, midwives who have good knowledge $\geq 70 \%$ of the questions were answered correctly (95.28\%) implemented PMTCT more than those who had knowledge $<70 \%$ of questions were answered correctly (24.75\%) and the difference was correctly statistically significant $(\mathrm{OR}=60.0 ; \mathrm{p}<0.001)$.

There is a relationship between job satisfaction and PMTCT program implementation, midwives who have satisfaction $\geq 1$ (72.97\%) implement PMTCT more than those who have satisfaction $<1(45.45 \%)$ and the difference is statistically significant $(\mathrm{OR}=$ 3.24; $\mathrm{p}<0.001$ ).

There is a relationship between the effect of the midwife's work environment on the implementation of the PMTCT program, midwives who have a good working environment (65.15\%) implement PMTCT more than those who have an unfavorable work environment (51.69\%) and the difference is statistically significant $(\mathrm{OR}=1.75 ; \mathrm{p}=0.077)$.
There is a correlation between the performance of midwives on the implementation of the PMT-CT program, midwives who have good performance (68.21\%) implement PMTCT more than those who have poor performance $(3.03 \%)$ and the dif ferrence is statistically significant $(\mathrm{OR}=68.6 ; \mathrm{p}<0.001)$.

There is a relationship between the influence of community support on the implementation of the PMTCT program, midwives who have strong community support (60.94\%) implement PMTCT more than those without community support (46.43\%) and the difference is statistically significant $(\mathrm{OR}=1.8 ; \mathrm{p}=0.068)$.

\section{The result of multivariate analysis}

Multivariate analysis explains the effect of more than one independent variable on one dependent variable. The multivariate analysis method used is the multilevel logistic regression of the Stata 13 program.

Table 4 shows the results of the multilevel analysis. Table 4 showed that there is an effect of the age of the midwife on the PMTCT program implementation and is statistically significant. Midwives aged >35 years had logodd to implement PMTCT program well 0.51 units lower than age $<35$ years $(b=-0.51 ; 95 \% \mathrm{CI}=-0.79$ to $-0.23 ; \mathrm{p}$ $<0.001)$.

There is an influence between tenure and the implementation of PMTCT program. Midwives who had tenure $\geq 8$ years had logodd to implement PMTCT program policies 0.50 units higher than midwives with tenure $<8$ years $(b=0.51 ; 95 \% \mathrm{CI}=0.16$ to $0.85 ; \mathrm{p}=0.004)$.

There is an effect of training on the implementation of PMTCT program policies and is statistically significant. Midwives who participate in training $\geq 2$ times had logodd to implement PMTCT program 0.44 units higher with midwives participating in training $<2(b=0.44 ; 95 \% \mathrm{CI}=0.13$ to 0.76 ; $\mathrm{p}=$ 0.005). 
There is an effect of midwives' knowledge on the implementation of PMTCT program policies and is statistically significant. Midwives who have knowledge $\geq 70 \%$ had logodd to implement PMTCT program policies well 0.65 units higher with midwives who have knowledge $<70 \%(b=0.65 ; 95 \% \mathrm{CI}=$ 0.36 to $0.93 ; \mathrm{p}<0.001)$.
There is an influence of job satisfaction on the implementation of PMTCT program policies and is statistically significant. Midwives who with high job satisfaction had logodd to implement PMTCT program 0.05 units higher $(\mathrm{b}=0.05 ; 95 \% \mathrm{CI}=-0.21$ to 0.31 ; $\mathrm{p}=0.694)$.

Table 3.The results of the bivariate analysis of the implementation of the PMTCT

\begin{tabular}{|c|c|c|c|c|c|c|c|c|}
\hline \multirow{3}{*}{ Independent variables } & \multicolumn{4}{|c|}{ PMTCT implementation } & \multirow{2}{*}{\multicolumn{2}{|c|}{ Total }} & \multirow{3}{*}{ OR } & \multirow{3}{*}{$\mathbf{p}$} \\
\hline & \multicolumn{2}{|c|}{ poor } & \multicolumn{2}{|c|}{ good } & & & & \\
\hline & $\mathbf{n}$ & $\%$ & $\mathbf{n}$ & $\%$ & $\mathbf{n}$ & $\%$ & & \\
\hline \multicolumn{9}{|l|}{ Midwife's Age } \\
\hline Young $(<35$ Years Old $)$ & 48 & 51.61 & 45 & 48.39 & 93 & 100 & 1.97 & 0.024 \\
\hline Old ( $\geq 35$ Years Old) & 32 & 35.16 & 59 & 64.84 & 91 & 100 & & \\
\hline \multicolumn{9}{|l|}{ Period of Working } \\
\hline Short $(<8$ Years Old $)$ & 66 & 72.53 & 25 & 27.47 & 91 & 100 & 14.9 & $<0.001$ \\
\hline \multirow{2}{*}{\multicolumn{9}{|c|}{ PMTCT Training }} \\
\hline & & & & & & & & \\
\hline No Training $(<2$ Times) & 63 & 66.32 & 32 & 33.68 & 95 & 100 & 8.34 & $<0.001$ \\
\hline Attending Training ( $\geq 2$ Times) & 17 & 19.10 & 72 & 80.90 & 89 & 100 & & \\
\hline \multicolumn{9}{|l|}{ Midwife's Knowledge } \\
\hline Poor $(<70 \%)$ & 76 & 75.25 & 25 & 24.75 & 101 & 100 & 60.04 & $<0.001$ \\
\hline Good $(\geq 70 \%)$ & 4 & 4.82 & 79 & 95.28 & 83 & 100 & & \\
\hline \multicolumn{9}{|l|}{ Job Satisfaction } \\
\hline Dissatisfied & 60 & 54.55 & 50 & $45 \cdot 45$ & 110 & 100 & 3.24 & $<0.001$ \\
\hline Satisfied & 20 & 27.03 & 54 & 72.97 & 74 & 100 & & \\
\hline \multicolumn{9}{|l|}{ Working Environment } \\
\hline Poor & 57 & 48.31 & 61 & 51.69 & 118 & 100 & 1.75 & 0.077 \\
\hline Good & 23 & 34.85 & 43 & 65.15 & 66 & 100 & & \\
\hline \multicolumn{9}{|l|}{ Midwife Performance } \\
\hline Poor & 32 & 96.97 & 1 & 3.03 & 33 & 100 & 68.67 & $<0.001$ \\
\hline Good & 48 & 31.79 & 103 & 68.21 & 151 & 100 & & \\
\hline \multicolumn{9}{|l|}{ Public Support } \\
\hline Weak & 30 & 53.57 & 26 & 46.43 & 56 & 100 & 1.8 & 0.068 \\
\hline Strong & 50 & 39.06 & 78 & 60.94 & 128 & 100 & & \\
\hline
\end{tabular}

There is an effect of midwife's performance on the implementation of the PMTCT program and is statistically significant. Midwives who have a good work environment had logodd to implement the PMTCT program policies 0.09 units lower than midwives with poor working environment $(b=-0.09 ; 95 \%$ $\mathrm{CI}=-0.35$ to $0.15 ; \mathrm{p}=0.451)$.

There is an influence of the work environment on the implementation of PMTCT program policies and is statistically significant. Midwives who have a good work envi- ronment had logodd to implement the PMTCT program 0.09 units lower than midwives with poor working environment $(b=-0.09$; $5 \% \mathrm{CI}=-0.35$ to $0.15 ; \mathrm{p}=0.451$ ).

There is an influence of community support on the implementation of PMTCT program and is statistically significant. Midwives with strong community support had logodd to implement PMTCT program 0.06 units lower than midwives with poor community support $(\mathrm{b}=-0.06 ; 95 \% \mathrm{CI}=-0.38$ to $0.25 ; \mathrm{p}=0.692)$. There is a contextual 
influence of community health centers on the implementation of PMTCT program policies.

Table 4 shows that the $\mathrm{ICC}=6.6 \%$, the indicator shows that the variation in the implementation of PMTCT program as much as $6.6 \%$ is determined by the Public Health
Centers variable. The results of multilevel analysis show the ICC value is smaller than the rule of thumb (8-10\%), so the contextual influence of the community health centers to consider.

Table 4. The results of multilevel multiple logistic regression analysis of factors that influence the implementation of PMTCT program policies by midwives

\begin{tabular}{|c|c|c|c|c|}
\hline \multirow{2}{*}{ Independent Variable } & \multirow{2}{*}{$\begin{array}{l}\text { Regression } \\
\text { coefficient (b) }\end{array}$} & \multicolumn{2}{|c|}{ CI95\% } & \multirow[b]{2}{*}{$\mathbf{p}$} \\
\hline & & Lower Limit & Upper Limit & \\
\hline \multicolumn{5}{|l|}{ Fixed effect } \\
\hline $\begin{array}{l}\text { Midwife's age ( } \geq 35 \text { years } \\
\text { old) }\end{array}$ & -0.51 & -0.79 & -0.23 & $<0.001$ \\
\hline $\begin{array}{l}\text { Period of working ( } \geq 8 \text { years } \\
\text { old) }\end{array}$ & 0.50 & 0.16 & 0.85 & 0.004 \\
\hline PMTCT training ( $\geq 2$ times) & 0.44 & 0.13 & 0.76 & 0.005 \\
\hline Knowledge ( $\geq 70 \%$ ) & 0.65 & 0.36 & 0.93 & $<0.001$ \\
\hline Job satisfaction (good) & 0.05 & -0.21 & 0.31 & 0.694 \\
\hline $\begin{array}{l}\text { Working environment } \\
\text { (good) }\end{array}$ & -0.09 & -0.35 & 0.15 & 0.451 \\
\hline $\begin{array}{l}\text { Performance of midwife } \\
\text { (good) }\end{array}$ & 0.59 & 0.25 & 0.93 & 0.001 \\
\hline Public support (strong) & -0.06 & -0.38 & 0.25 & 0.692 \\
\hline \multicolumn{5}{|l|}{ Random effect } \\
\hline \multicolumn{5}{|l|}{ Community health center } \\
\hline Var (Constanta) & 0.06 & 0.01 & 0.34 & \\
\hline $\mathrm{N}$ observes $=184$ & & & & \\
\hline N Public Health Centers $=26$ & & & & \\
\hline Log likelihood= -223.43 & & & & \\
\hline $\mathrm{ICC}=6.6 \%$ & & & & \\
\hline
\end{tabular}

\section{DISCUSSION}

1. The effect of midwife age on the implementation of PMTCT program

The results showed that there was an effect of midwife age on the implementation of PMTCT program policies and was statistically significant $(b=-0.51 ; \mathrm{CI} 95 \%=-0.79$ to $-0.23 ; \mathrm{p}$ $<0.001)$.

Adriansyah's study (2017) shows that midwives who are more mature (over 36 years) have better social awareness because they have experience in interacting with the social world. Midwives who work longer hours (more than 10 years) tend to have better social awareness. The age of the midwife and the length of work of the midwife have a significant effect on the midwife's social awareness.

\section{The effect of tenure on the imple- mentation of PMTCT program}

The results showed that there was an effect of midwives' period of working on the implementation of PMTCT program policies and was statistically significant. Midwives who have $\geq 8$ years of working had logodd to implement PMTCT program 0.50 units higher than midwives with tenure $<8$ years $(b=0.51$; $95 \% \mathrm{CI}=0.16$ to $0.85 ; \mathrm{p}=0.004)$.

The period of working can illustrate a person's experience in mastering the area of their duties. In general, officers with a lot of work experience do not need guidance compared to officers with little work experience.

Generally midwives with longer work experience tend to have better social aware- 
ness. In this study, the length of work over 10 years has a relationship with the social awareness of the midwife than those who have worked under 10 years. This is based on the fact that midwives with more experience in serving pregnant women will grow in themselves with better social awareness. This is in line with the Golemane theory which states that social awareness grows and develops in line with the increasingly nurtured and strengthened self in sufficient time.

\section{The effect of midwife training on the implementation of PMTCT program policies}

The results showed that there was an effect of training on the implementation of PMTCT program policies and was statistically significant. Midwives who participate in training $\geq 2$ times had logodd to implement PMTCT program policies well 0.44 units higher with midwives participating in training $<2(\mathrm{~b}=$ $0.44 ; 95 \% \mathrm{CI}=0.13$ to $0.76 ; \mathrm{p}=0.005$ ).

Midwives as the spearhead of health services for pregnant women, birth and maintenance of maternal and child health, have an important role in efforts to suppress the rate of growth of HIV/AIDS among community groups visiting Public Health Centers and Hospitals, especially in $\mathrm{MCH} / \mathrm{KB}$ services. Midwives are trained to have knowledge about preventing transmission of HIV/AIDS from infants. The process of transmission of HIV/AIDS can take place through the process of childbirth, as well as the process of giving breast milk to babies. These risky conditions require cross-institutional, government and private commitments to create various programs and activities, optimally to prevent transmission of HIV/AIDS from child mothers (Jamaludin, 2013).

The behavior of midwives in implementing PMTCT must really be considered. In addition to having special skills in promoting programs, midwives must also know the ins and outs of understanding about HIV-
AIDS. Midwives are expected to be able to understand the conditions that exist in the client so that the client feels comfortable and is willing to take steps from the PMTCT (Prevention of Mother to Child Transmission) program. Midwives are expected to be careful about anamnese pregnant women (pregnant women) about the presence or absence of risk factors for HIV infection. In addition, pregnant women are expected to voluntarily go to a VCT clinic. The purpose of VCT activities is to detect whether a person (mother and husband) has HIV or not.

\section{The effect of midwife knowledge on the implementation of PMTCT prog ram}

The results showed that there was an effect of midwives' knowledge on the implementation of PMTCT program policies and was statistically significant. Midwives who have knowledge $\geq 70 \%$ had logodd to implement PMTCT program 0.65 units higher with midwives who have knowledge $<70 \%(\mathrm{~b}=$ $0.65 ; 95 \% \mathrm{CI}=0.36$ to 0.93 ; $\mathrm{p}<0.001$ ).

Knowledge itself is influenced by formal education factors. Knowledge is very closely related to education, where it is expected that with higher education the person will also be more knowledgeable. However, it needs to be emphasized that it does not mean that someone with low education is absolutely low in knowledge either. Someone's knowledge about an object contains two aspects, namely positive and negative aspects. These two aspects will determine a person's attitude the more positive aspects and objects that are known, it will lead to a more positive attitude towards certain objects (Dewi and Wawan, 2010).

High rates of mother-to-child HIV transmission (MTCT) may contribute to an increase in pandemic rates. Research conducted by Nkwabong et al. (2018) stated that knowledge is very important in implementing 
PMTCT program policies by midwives and has a significant influence $(\mathrm{AOR}=9.01 ; 95 \%$ $\mathrm{CI}=1.82$ to 48.60 ).

\section{The effect of job satisfaction on the implementation of PMTCT}

The results of this study indicate that there is an effect of job satisfaction on the implementation of PMTCT program policies and is statistically significant. Midwives who have job satisfaction $\geq 1$ had logodd to implement PMTCT program 0.05 units higher with midwives who have less job satisfaction $(b=$ $0.05 ; 95 \% \mathrm{CI}=-0.21$ to $0.31 ; \mathrm{p}=0.694$ ).

Individuals influence the role in work and the characteristics of the job. Job satisfaction depends on whether the person feels a sense of equity (equity) or not for what has been done and what was obtained. This feeling of satisfaction or dissatisfaction is obtained by comparing himself with others in his own organization or comparing what he used to get with what he is currently getting (Dugguh and Dennis, 2014).

A study by Schuster et al. (2016) states that dissatisfaction of health personnel with salaries, incomplete medical record records, workload overload, and out of stock can turn service values and feedback into motivation (Topp et al. 2015). Conversely, a supportive interpersonal environment (for example, recognition, assistance, training) and adequate infrastructure (including workload, inventory, equipment) are the main dimensions of facility-based worker satisfaction being highly motivated, further investigation of the interpersonal environment of workers and the effects of barriers on the value of guaranteed services, including identifying and reducing inefficiencies in the workflow (Mbaruku et al, 2014).

\section{The effect of midwife performance on the implementation of PMTCT program}

The results of this study indicate that there is an influence of team performance on the implementation of PMTCT program policies and is statistically significant. Midwives who have a good work environment had logodd to implement the PMTCT program policies well 0.09 units lower with midwives who have a poor working environment $(b=-0.09 ; 95 \%$ $\mathrm{CI}=-0.35$ to $0.15 ; \mathrm{p}=0.451)$.

Performance is the result of work or work performance. In fact the performance is not only as a result of a job, but also there is a description of the implementation of the work (Nursalam, 2007). Performance can also mean the results of a planned work implementation process, involving time, place, executor or employee of an institution (Mangkunegara, 2007).

The Ministry of Health of the Republic of Indonesia Number 36 of 2009 concerning Health Article 152, 2014 states that the government, regional government and the community are responsible for carrying out prevention, control and eradication of infectious diseases and their consequences. Efforts to prevent, control and eradicate infectious diseases are carried out to protect the community from contracting diseases, reduce the number of sick, disabled and/or die, and to reduce the social and economic impacts of infectious diseases.

\section{The effect of Working Environment on the implementation of PMTCT program}

The results of this study indicate that there is an influence of the work environment on the implementation of PMT-CT program policies and is statistically significant. Midwives who have a good work environment had logodd to implement PMTCT program policies well 0.09 units lower with midwives who have a poor working environment $(b=-0.09$; 95\% $\mathrm{CI}=-0.35$ to $0.15 ; \mathrm{p}=0.451)$.

The working environment is one thing that requires important attention in an organization, both the physical work environment and non-physical work environment. 
Sedarmayati (2009) states that the work environment is the overall tools and materials faced, the surroundings in which a person works, the method of work, and work arrangements both individually and in groups. Facilities and infrastructure in accordance with adequate service standards in implementing PMTCT programs must be adequate.

The study of Smith et al. (2018) shows that some obstetric and pediatric centers in Atlanta MSA do not follow standard care guidelines, which include assessing the mother's HIV status during labor by conducting a rapid test. Almost all service providers are unaware of the National HIV Clinic Consultation Center, a free 24-hour resource that provides advice on standard and fast HIV indications and interpretations in pregnancy and consultation on antiretroviral use in pregnancy, during labor and delivery, and in the postpartum period.

\section{The effect of community support on the implementation of PMTCT program}

The results of this study indicate that there is an influence of community support for the implementation of PMTCT program policies and is statistically significant. Midwives who have strong community support had logodd to implement PMTCT program policies well 0.06 units lower with midwives who have poor community support $(\mathrm{b}=-0.06$; $95 \% \mathrm{CI}=$ -0.38 to $0.25 ; \mathrm{p}=0.692$ ).

The Ministry of Health of the Republic of Indonesia in the PMTCT National Guidelines states that PMTCT (Prevention of Mother to Child Transmission) is a program to stop the transmission of HIV/AIDS from pregnant pregnant women conceived, starting from preventing transmission of HIV/AIDS to high productive age groups to providing support psychologically and socially for mothers and infants with HIVAIDS.

Prevention of Transmission of HIV/-
AIDS from Mother to Child (PPIA) is a program to prevent the transmission of HIV/AIDS from mother mothers. The basic concept is to reduce Viral Load as low as possible, minimizing fetal/infant exposure to HIV positive body fluids, then optimizing the health of infants from mothers with HIV so that support from families and health personnelss is needed. In addition to medical efforts, HIV mothers need psychological and social support from people around them, especially their families and the environment, including health personnel in preventing HIV transmission from childbirth (Solikha, 2008).

Community support can be seen from the awareness of mothers in the prevention of HIV transmission to infants by conducting examinations in antenatal health services to receive HIV testing, those diagnosed with HIV are positive registered in the prevention of vertical transmission of HIV services and for their babies tested through the EID strategy (early infant diagnosis) (Nsubuga et al. 2019).

\section{The effect of contextual effect of community health centers on the implementation of PMTCT program}

Table 4 shows that the ICC value $=6.6 \%$, the indicator shows that the variation in the implementation of PMTCT program policies as much as $6.6 \%$ is determined by the Public Health Centers variable. The results of multilevel analysis show the ICC value is smaller than the rule of thumb (8-10\%), so the contextual influence of the Public Health Centers is not important to consider.

Republic of Indonesia Minister of Health Regulation No. 75 of 2014 concerning community health centers, Public Health Centers is a health service facility that organizes public health efforts and first-level individual health efforts, prioritizing promotive and preventive efforts, to achieve the highest degree of public health in the working area. 
Public Health Centers is also a health service facility which is the mainstay or benchmark of health development, a means of community participation, and the first comprehensive service from an area (Ministry of Health, 2014).

Public Health Centers was established to provide basic, comprehensive, complete and integrated health services for all residents living in the Public Health Centers working area. Health programs and efforts organized by Public Health Centers are the main public health essential programs that must be carried out by the government to realize community welfare (Sulaeman, 2014).

Public Health Centers have the authority and responsibility to provide health services to all administratively residents who are domiciled in the Public Health Centers working area. Forms of health services provided by health centers are comprehensive (comprehensive health care services), namely health services that include aspects of promotive, preventive, curative and rehabilitative (Sulaeman, 2014).

\section{AUTHOR CONTRIBUTION}

Sringatin is the main researcher who played a role in collecting and processing research data; Uki Retno Budi Hastuti examined the conceptual framework and methodology; Endang Sutisna Sulaeman analyzed the research draft.

\section{CONFLICT OF INTEREST}

There is no conflict of interest.

\section{FUNDING AND SPONSORSHIP}

This study is self-funded.

\section{ACKNOWLEDGEMENT}

We would like to show our gratitude to Public Health Centers for helping with the research and also to the respondents who have participated and were willing to become the subjects.

\section{REFERENCE}

InHurst SA, Appelgren KE, Kourtis AP. (2015). Prevention of mother-to-child transmission of HIV Type 1: The role of neonatal and infant prophylaxis. Expert Rev AntiInfect Ther, 13(2): 169-181. https://doi.org/10.1586/14787210.2015.999667

Dugguh S, Dennis A. (2014). Job satisfaction theories: Traceability to employee performance in organizations. IOSR Journal of Business and Management, 16(5): 11-18. https://doi.org/10.9790/487x16511118

Ministry of Health RI (2014). Undang-Undang No. 36 Tentang Tenaga Kesehatan. Ministry of Health RI, (1): 2. Retrieved from http://gajiroum.kemkes.go.id/gajiroum/data/UU_NO_36_2014.pdf

MbarukuGM, Larson E, Kimweri A, Kruk ME (2014). What elements of the work environment are most responsible for health personnels dissatisfaction in rural primary care clinics in Tanzania, 12(1): 1-9. https://doi.org/10.1186/1478-4491-1238

Nkwabong E, Nguel RM, Kamgaing N, Sylvie A, Jippe K (2018). Knowledge, attitudes and practices of health personnel of maternities in the prevention of motherto-child transmission of HIV in a subSaharan African region with high transmission rate : some solutions proposed. 1-6.https://doi.org/10.1186/s12884-018-1876-O

Nsubuga S, Meadway J, Olupot-olupot P (2019). A study using knowledge, attitude and practices on the prevention of HIV-1 vertical transmission with outcomes in early infant HIV-1 diagnosis in Eastern Uganda. 102-108.https://www.ncbi.nlm.nih.gov/pubmed/31191913. Read JS, Havens P, Emmanuel P, Flynn P, Henry-Reid L, Hoyt L, et al. (2007). Diagnosis of HIV-1 infection in children 
younger than 18 months in the United States. Pediatrics, 120(6). https://doi.org/10.1542/peds.2007-2951

Schuster RC, Sousa O De, Rivera J, Olson R, Pinault D (2016). Performance-based incentives may be appropriate to address challenges to delivery of prevention of vertical transmission of HIV services in rural Mozambique : a qualitative investigation. Human Resources for Health. https://doi.org/10.1186/s12960-0160157-0

Smith SL, Chahroudi AM, Camacho-gonzalez AF, Gillespie S, Wynn BA, Badell ML, et al. (2018). Evaluating facility infrastructure for prevention of mother-tochild transmission of HIV-A 2015 Assessment of Major Delivery Hospitals in Atlanta, Georgia. J Pediatric Infect Dis Soc. 7(3): e102-e106. https://doi.org/10.1093/jpids/piyo58
Sulaeman ES (2014). Manajemen kesehatan teori dan praktik di Public Health Centers ( $3^{\text {rd }}$ ed) (Health management theory and practice at Public Health Centers (3rd ed). Yogyakarta: Gadjah Mada University Press.

Topp SM, Chipukuma JM, Hanefeld J (2015). Understanding the dynamic interactions driving Zambian health centre performance: A case-based health systems analysis. Health Policy Plan. https://doi.org/10.1093/heapol/czuo29 Widjajanti M (2016). Evaluasi program prevention of mother to child HIV Transmission (PMTCT) di RSAB Harapan Kita Jakarta (Evaluation of HIV Transmission (PMTCT) prevention of mother to child program at RSAB Harapan Kita Jakarta). Sari Pediatri, 14(3): 167. https://doi.org/10.14238/sp14.3.2012.1$67-72$ 